\title{
Evaluation of Consortia performance under continuous process treating municipal wastewater with low concentration of heavy metals, antibiotic (gentamicin) and diesel oil
}

\author{
Kanhaiya Kumar Singh $^{\# 1}$, R. C. Vaishya ${ }^{* 2}$, Arnav Gupta ${ }^{\circledR 3}$ \\ \# Research Scholar, Department of Civil Engineering, \\ Motilal Nehru National Institute of Technology-Allahabad, 211004, India \\ ${ }^{1}$ rce1454@mnnit.ac.in \\ * Professor, Department of Civil Engineering, \\ Motilal Nehru National Institute of Technology-Allahabad, 211004, India \\ ${ }^{2}$ rcvaishya@mnnit.ac.in \\ @ B. Tech Student, Department of Civil Engineering, \\ Birla Institute of Technology \& Science, Pilani-333031, Rajasthan, India \\ ${ }^{3}$ arnavcooldude7@gmail.com
}

\begin{abstract}
The objective was to investigate the effect of heavy metals, antibiotic and diesel oil at low concentrations in an Upflow Anaerobic Sludge Blanket (UASB) reactor performance under continuous conditions and also evaluate metals geochemical distribution in anaerobic sludge analyzed by sequential extraction method. A lab scale UASB reactor was inoculated with prepared sludge (Cow dung + specialized Consortia developed from municipal wastewater) and allowed to acclimate during 2 months. After acclimation period, three different concentrations of five heavy metals, diesel oil and antibiotic(gentamicin) having equal ratio as well as found in municipal wastewater (Zn: $1.82,3.64$ \& 7.28 mg/l; Pb: 0.44, 0.88 \& 1.76 mg/l; Cu: 0.30, 0.60 \& 1.20 mg/l; Cd: 0.18, 0.36 \& 0.72; Cr: 0.06, 0.12 \& 0.24

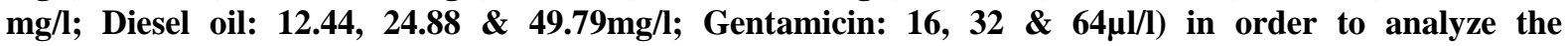
performance of an UASB reactor treating municipal wastewater with low metals, diesel oil and antibiotic concentrations during one month for each one. The result of sequential extractions showed that the major affinity with heavy metals found organic/sulfide bound, with $96 \%$ percentage distribution. Reactor performance affected through augments caused a total alkalinity diminution in the effluent; while the system buffer capacity was sufficient to overcome such instability, as the ratio of partial alkalinity/total alkalinity confirmed. Removal of COD decreased up to $15 \%$ when higher doses were added in comparison to acclimation period. Addition of lower doses in reactor influent affected adversely its performance; although, did not cause entire inhibition to anaerobic microbes..
\end{abstract}

Keyword - Antibiotic, sequential extraction, metals geochemical distribution, buffer capacity, UASB reactor.

\section{INTRODUCTION}

Anaerobic treatment is suitable and appropriate technology to treat municipal wastewater in developing countries due to its lower operational costs, easy handling and generation of valuable products [1]. The presence of inhibitory and toxic substances in municipal wastewater is often the major cause of dropping anaerobic system since they could be present there. Those substances include antibiotics, oil and grease, sulfide, complex organics and heavy metals [2]. Among the above group, some heavy metals and pharmaceutical residues have been identified as a main concern for anaerobic treatment systems since it inhibits methanogenesis processes [3], affects degradation of volatile fatty acids (VFA) and have the highest binding capacity to the reactor anaerobic sludge [4-5]. Generally heavy metals are important trace elements and are also cofactors for several enzymes [6]; however, these metal ions can interact with intracellular clusters of several proteins and inhibit their activity during the process under anaerobic conditions [7]. Asian water commission implies that metals, oil and grease, pharmaceutical residues presence in municipal wastewater is associated with wood preservatives, fungicides, corrosion, pigments, parricides, leaching of plumbing and antifouling paints [8]. Total heavy metals and other toxic substances may illustrate their overall accumulation level in sludge, mobility, and bioavailability and also related eco-toxicity to reactor system; ultimately depend on their ways of binding or specific chemical forms [9-10]. Therefore, this is very essential to quantify and identify the different strains, phases or forms available in the sludge, in order to evaluate the toxic effects on anaerobic microbes [11-12]. The quantification and identification process is also known as chemical speciation; it can be divided into five fractional parts and each fraction obtains migration behavior and distinctive characteristics in the result matrix. It means that each fractional part can play a specific role considering owns toxicity to living beings [13-14]. 
Some research work has been done to access the effects of heavy metals on granular sludge in Upflow Anaerobic Sludge Blanket (UASB) reactors, including metal speciation analysis [15-16]. As experimented regarding synthetic wastewater containing copper, among other metals, in order to evaluate the short-term impact of copper exposure on methanogenesis [17-18]. It was investigated that the effect of the heavy metal absence on the conversion of volatile fatty acids by a distillery anaerobic sludge [19]. Van Hullebusch et al. [20] compared the extraction efficiencies of heavy metals in leaching process from anaerobic sludge. Zandvoort et al. [21] stated about content of trace element and effects of deficiency in anaerobic sludge from UASB reactors. Aquino and Stuckey [22] evaluated the effect of metal complexity on toxicity and bioavailability in a continuously stirred tank reactor (CSRT). So far, there is no investigation on geochemical distribution of toxic heavy metals in granular sludge from UASB reactors through metal speciation while UASB reactor is used to treat real municipal wastewater containing heavy metals, antibiotic (gentamicin), oil and grease(diesel oil) at low concentrations for long-term operation. Thus, the objective of present work was to investigate the effect of heavy metals, antibiotic and diesel oil at low concentrations in an Upflow Anaerobic Sludge Blanket (UASB) reactor performance under continuous conditions and also evaluate metals geochemical distribution in anaerobic sludge analyzed by sequential extraction method. The results obtained in an experiment at lab-scale in which Upflow Anaerobic Sludge Blanket reactor was operated under hydraulic retention time (HRT) 7.5 hours, sludge retention time (SRT) of 90 days and fed with three different concentrations of five heavy metals, diesel oil and antibiotic(gentamicin) having equal ratio as well as found in municipal wastewater (Zn: 1.82, 3.64 \& $7.28 \mathrm{mg} / \mathrm{l}$; Pb: 0.44, 0.88 \& 1.76 mg/l; Cu: 0.30, 0.60 \& 1.20 mg/l; Cd: 0.18, 0.36 \& 0.72; Cr: 0.06, 0.12 \& 0.24 mg/l; Diesel oil: 12.44, $24.88 \& 49.79 \mathrm{mg} / \mathrm{l}$; Gentamicin: 16, $32 \& 64 \mu \mathrm{l} / \mathrm{l})$ in order to evaluate the performance of an UASB reactor.

\section{Experimental Set Up}

Upflow Anaerobic Sludge Blanket (UASB) reactor was made of Perspex material, containing rectangular section (at the bottom) and an expanded section (at the top) termed as gas-liquid-solid separator (GLSS). Rectangular part is a $120 \mathrm{~cm}$ long column with $12.4 \mathrm{~cm}$ length as well as $12.4 \mathrm{~cm}$ width and having a volume of 4.6 L. The length of the GLSS was $40 \mathrm{~cm}$ and volume was $10.2 \mathrm{~L}$. The GLSS was further divided into two parts; bottom half was tapered with a slope of $60^{\circ}$ and top half was a $20 \mathrm{~cm}$ rectangular column with $38.98 \mathrm{~cm}$ length and $38.98 \mathrm{~cm}$ width (Table1). A lab scale UASB reactor was inoculated with prepared sludge (Cow dung + specialized Consortia developed from municipal wastewater) and allowed to acclimate during 2 months. A sample of inoculum and anaerobic sludge was stored at $4^{\circ} \mathrm{C}$ in order to analyse metal speciation. Municipal wastewater was regularly collected from railway pullia sewerage line near MNNIT Campus Allahabad and also characterized. The results of wastewater characterization are provided in Table 2. The temperature of UASB reactor was maintained at $21^{\circ} \mathrm{C}$ (approx.) and operated under a hydraulic retention time of 7.5 hours. The sludge retention time was maintained at approximately 90 days, including start up time. Municipal wastewater was pumped to the UASB reactor using a peristaltic pump. After an acclimation period of two months, fed municipal wastewater with three different concentrations of five heavy metals, diesel oil and antibiotic(gentamicin) having equal ratio as well as found in municipal wastewater (Zn: 1.82, 3.64 \& $7.28 \mathrm{mg} / \mathrm{l}$; Pb: 0.44, 0.88 \& $1.76 \mathrm{mg} / \mathrm{l}$; Cu: 0.30, 0.60 \& $1.20 \mathrm{mg} / \mathrm{l}$; Cd: 0.18, 0.36 \& 0.72; Cr: 0.06, 0.12 \& $0.24 \mathrm{mg} / \mathrm{l}$; Diesel oil: 12.44, 24.88 \& $49.79 \mathrm{mg} / \mathrm{l}$; Gentamicin: 16, $32 \& 64 \mu \mathrm{l} / \mathrm{l})$ in order to evaluate the performance of an UASB reactor. Each augment dose [X1(Zn: $1.82 \mathrm{mg} / \mathrm{l}$; Pb: $0.44 \mathrm{mg} / \mathrm{l}$; Cu: $0.30 \mathrm{mg} / \mathrm{l}$; Cd: $0.18 \mathrm{mg} / \mathrm{l}$; Cr: $0.06 \mathrm{mg} / \mathrm{l}$; Diesel oil: 12.44

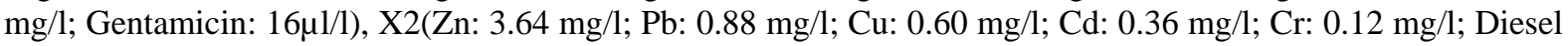
oil: $24.88 \mathrm{mg} / \mathrm{l}$; Gentamicin: $32 \mu \mathrm{l} / \mathrm{l}$ ) and X3(Zn: $7.28 \mathrm{mg} / \mathrm{l}$; Pb: $1.76 \mathrm{mg} / \mathrm{l}$; Cu: $1.20 \mathrm{mg} / \mathrm{l}$; Cd: $0.72 \mathrm{mg} / \mathrm{l}$; Cr: $0.24 \mathrm{mg} / \mathrm{l}$; Diesel oil: $49.79 \mathrm{mg} / \mathrm{l}$; Gentamicin: $64 \mu \mathrm{l} / \mathrm{l}$ )] was applied to the UASB reactor for a month (Table 3). A sample of anaerobic sludge was stored at $4^{\circ} \mathrm{C}$ for metal speciation analysis at the end of the experiment.

\section{Analytical Methods}

The $\mathrm{pH}$ and temperature were measured daily in UASB reactor influent and effluent using an Ion specific electrode for each parameter. Total alkalinity, pH, VFA \& COD were analysed according to the Standard Methods for the Examination of Water and Wastewater [23]. The ratio between partial and total alkalinity (PA/TA ratio) was calculated according to Soto et al. [24]. Metal concentrations in UASB influent and effluent were measured one time in a week by atomic absorption spectrophotometry (Model SOLAAR M6, Thermo Elemental, USA).

\section{Metal Speciation}

Prior to metal speciation, samples of UASB reactor sludge previously refrigerated were frozen and then freeze dried. After that, UASB reactor sludge samples for metal speciation were separated into fractions by a multi extract technique. In this technique, metals are removed sequentially based on the strength of their attachment to the sludge. Freeze dried samples of UASB reactor sludge $(0.5 \mathrm{~g})$ were treated with a series of 
solvents in order to perform sequential extractions, which consist of several sequential steps which gave rise to five different fractions.

Blanks were analyzed in the fractions where analytical grade reagents were used. The samples were stirred using an orbital shaker at 50 RPM. After the addition of each solvent, liquid was then separated using a centrifuge at $4500 \mathrm{RPM}$ for $5 \mathrm{~min}$, the solids were washed twice with deionized water $(10 \mathrm{ml})$ and recovered by further centrifugation and then freeze dried. The liquids obtained from each fraction were filtered through a glass microfiber paper (Whatman, GF/B). The filtrate obtained was acidified to $\mathrm{pH} 2$ with nitric acid. Metal concentrations in each one of these filtrates were measured in duplicate by UV spectrophotometry [25].

Acid Digestions

Total copper concentration in UASB reactor sludge were determined in triplicate by acid digestions with 0.5 $\mathrm{g}$ of freeze-dried sample, $5 \mathrm{ml}$ of nitric acid (Analytical grade, J.T. Baker), $1 \mathrm{ml}$ of hydrofluoric acid (Analytical grade, J.T. Baker) and $5 \mathrm{ml}$ of de-ionized water. The samples were placed in a Teflon vessel and digested during 30 min using a microwave digestion system (Model Mars 5, CEM, USA). Acid digestions were performed three times until the samples were completely dissolved. Blanks were carried out for each sample.

Preparation of sludge sample for Scanning Electron Microscope

First of all bacterial broth were centrifuged followed by pellet washed with phosphate buffer saline for 3 times. After that $0.25 \%$ gluteraldehyde (in na-phosphate, ph 7.2) was added and incubated at room temperature for 30 minutes then incubated overnight. Again washed with na- phosphate buffer for 3 times then collected pellets through centrifugation and after that sample was dehydrolysed by different ethanol volumes starting; $30 \%, 50 \%, 70 \%, 80 \%, 90 \%$ and $100 \%$ and for each ethanol volume incubate for 10 minutes followed by sample incubated in $100 \%$ ethanol [26].

Minimum inhibitory concentration for analysis of antibiotic degradation

Minimum inhibitory concentration (MIC) depicts a low concentration of antibiotics which prevents visible growth of microbes. The MIC of antibiotic (gentamicin) is determined by preparing solutions of the antibiotic in vitro at increasing concentrations, incubating the solutions with the separate batches of cultured bacteria, and measuring the results using agar dilution or broth micro dilution.

\section{III.RESULTS AND DISCUSSION}

\section{Metal Speciation in the UASB Reactor Sludge}

The mass of metals recovered from sequential extraction scheme in UASB reactor sludge. The sum of all fractions is similar to the total contents achieved after acid digestion for each samples. Recoveries were found up to $95 \%$ for each sample, values were found almost similar as well as reported in the literature [27], which makes sense the reliability and validity of the achieved results. These results illustrate that metal removal in UASB reactor ranged from $45 \%$ to $90 \%$, confirming the previous observations. With the metal values obtained in UASB influent and effluent also considering as the mass of sludge present in the reactor $(0.923 \mathrm{~kg})$ it was possible to calculate approximately the mass of metal retained in the UASB reactor, which was $7245.86 \mathrm{mg}$ metals/kg sludge, result that is in a very good agreement with data presented in Table 4 . These metals are in a certain amount knowing trace element and are a cofactor for various enzymes [28]; however, is nonbiodegradable and only it can bio accumulate within the microbial cell to a certain level of toxic concentration [29]. Generally heavy metals have a short term capability to bind/ fix within the granules of sludge which are affected itself to protein and acid groups of sludge [30].

Table 1 UASB Reactor Speciation

\begin{tabular}{|c|c|c|}
\hline S. No. & Particulars & UASB reactor \\
\hline $\mathbf{1}$ & Material & Perspex \\
\hline $\mathbf{2}$ & Shape & rectangular \\
\hline $\mathbf{3}$ & Column cross section area & $12.4 \times 12.4 \mathrm{~cm} 2$ \\
\hline $\mathbf{4}$ & Height & $160 \mathrm{~cm}$ \\
\hline $\mathbf{5}$ & Diameter of feed inlet pipe (Bottom) & $2.5 \mathrm{~cm}$ \\
\hline $\mathbf{6}$ & Diameter of outlet (Top) & $2.5 \mathrm{~cm}$ \\
\hline $\mathbf{7}$ & Diameter of sampling ports & $2.5 \mathrm{~cm}$ \\
\hline $\mathbf{8}$ & Shape of GLSS & $\begin{array}{r}\text { The GLSS section was further divided into two parts; } \\
\text { bottom half was tapered with a slope angle (Ø) of } \\
60^{\circ} \text { and top half was a 20 cm long rectangular column } \\
\text { with 38.98 cm length and 38.98 cm width. }\end{array}$ \\
\hline
\end{tabular}


Table 2 Characteristics of municipal wastewater

\begin{tabular}{|c|c|}
\hline Parameter & Value \\
\hline $\mathrm{pH}$ & $8.11 \pm 1.01$ \\
\hline${\text { Temperature }\left({ }^{\circ} \mathrm{C}\right)}$ & $23.45 \pm 2.65$ \\
\hline Dissolved Oxygen(mg/l) & $0.32 \pm 0.13$ \\
\hline BOD(mg/l) & $98.49 \pm 11.57$ \\
\hline Total COD(mg/l) & $211.59 \pm 86.32$ \\
\hline Alkalinity $(\mathrm{mg} / \mathrm{l} \mathrm{CaCO3)}$ & $232.22 \pm 10.54$ \\
\hline Zinc(mg/l) & $0.91 \pm 0.21$ \\
\hline Lead(mg/l) & $0.22 \pm 0.02$ \\
\hline Copper(mg/l) & $0.15 \pm 0.03$ \\
\hline Cadmium $(\mathrm{mg} / \mathrm{l})$ & $0.09 \pm 0.02$ \\
\hline Chromium $(\mathrm{mg} / \mathrm{l})$ & $0.03 \pm 0.01$ \\
\hline Oil and grease $(\mathrm{mg} / \mathrm{l})$ & $6.22 \pm 0.92$ \\
\hline Gentamicin $(\mu / \mathrm{l} /)$ & $8 \pm 0.42$ \\
\hline
\end{tabular}

Table 3 Composition of simulated municipal wastewater

\begin{tabular}{|c|c|c|c|}
\hline \multirow{2}{*}{ Additional Parameters } & \multicolumn{3}{|c|}{$\begin{array}{c}\text { UASB Reactor Setup ( HRT=7.5hrs, } \\
\text { SRT=90days) Up flow velocity= 1.95 l/h }\end{array}$} \\
\cline { 2 - 4 } & X1 & X2 & X3 \\
\hline Zinc(mg/l) & 1.82 & 3.64 & 7.28 \\
\hline Lead(mg/l) & 0.44 & 0.88 & 1.76 \\
\hline Copper(mg/l) & 0.30 & 0.60 & 1.20 \\
\hline Cadmium(mg/l) & 0.18 & 0.36 & 0.72 \\
\hline Chromium(mg/l) & 0.06 & 0.12 & 0.24 \\
\hline Oil and grease(mg/l) & 12.44 & 24.88 & 49.79 \\
\hline Gentamicin $(\mu \mathrm{l} / \mathrm{l})$ & 16 & 32 & 64 \\
\hline
\end{tabular}

\section{UASB Reactor Performance}

Figs. 1 show pH values throughout experiment for UASB Reactor influent and effluent. Fig. 1 also indicate that the values of effluent similar as influent values. The $\mathrm{pH}$ values in municipal wastewater were found between 7.5 and 9, which are greater than those that generally occur in any domestic wastewater; this might be associated with the fact that sewage in Railway Pullia MNNIT Campus also collects wastewater generated in industries and laboratories. For reactor operation, $\mathrm{pH}$ values in UASB reactor should be slightly basic (7.3 - 8.7), which was found during the entire experiment. Total alkalinity values (Fig. 2) were higher during acclimation than in the period where $\mathrm{X} 1, \mathrm{X} 2$ and $\mathrm{X} 3$ doses were added to UASB influent; probably due to addition of X1, $\mathrm{X} 2$ and X3 doses caused volatile fatty acids (VFA) accumulation inside the UASB reactor which produced alkalinity consumption inside the UASB reactor and consequently its drop in effluent [31].

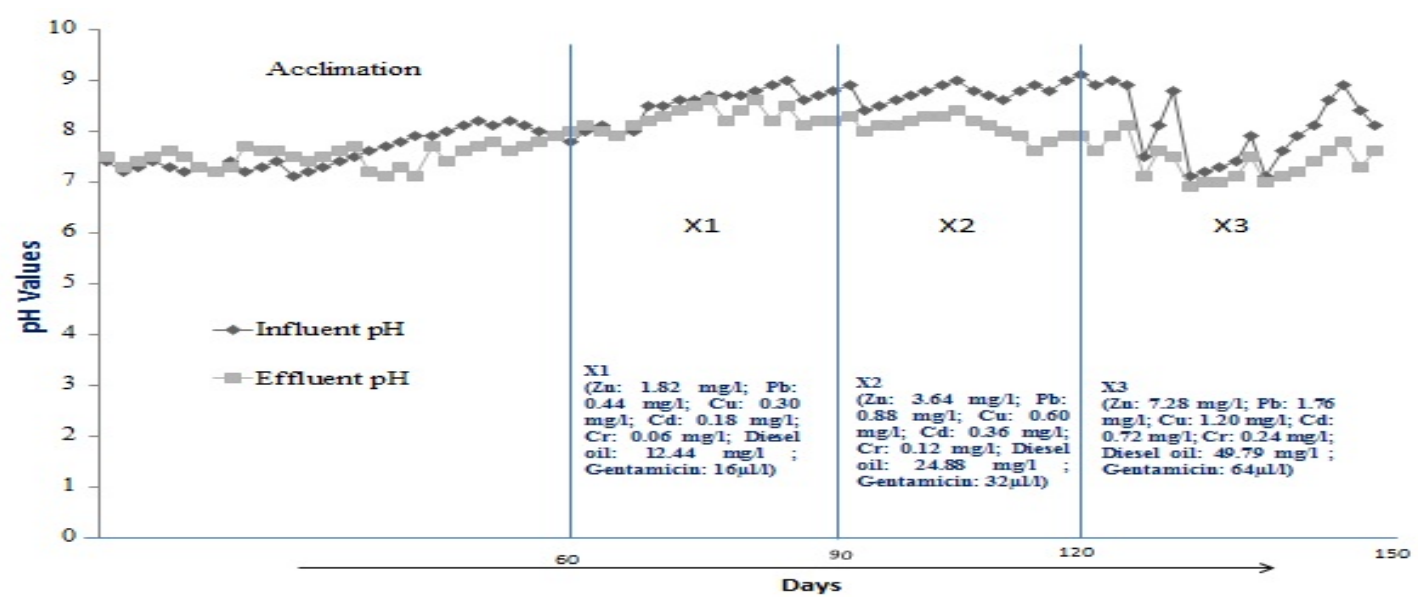

Fig. $1 \mathrm{pH}$ values in UASB Reactor influent and effluent throughout the entire experiment 


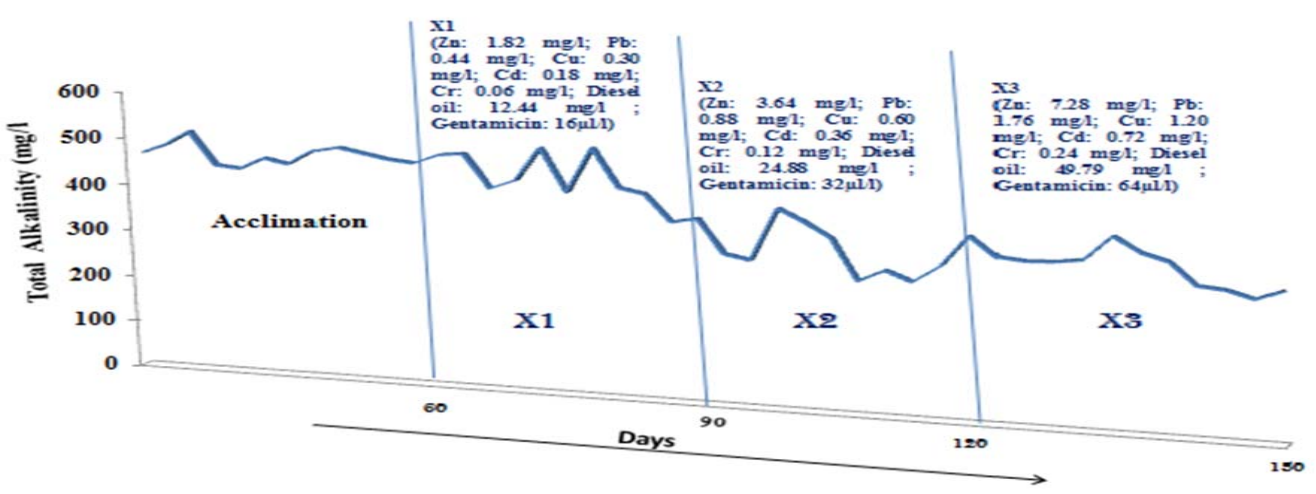

Fig. 2 Total alkalinity values in UASB Reactor effluent throughout the entire experiment

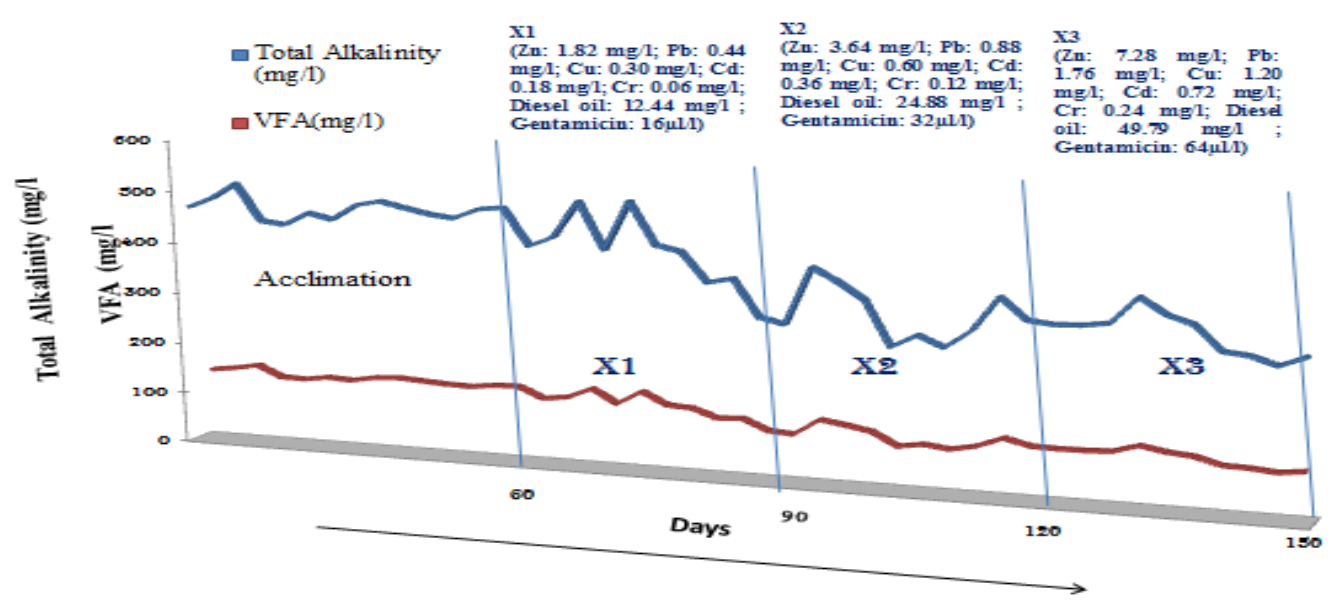

Fig. 3 Total alkalinity and Volatile Fatty Acid (VFA) values in UASB Reactor effluent throughout the entire experiment

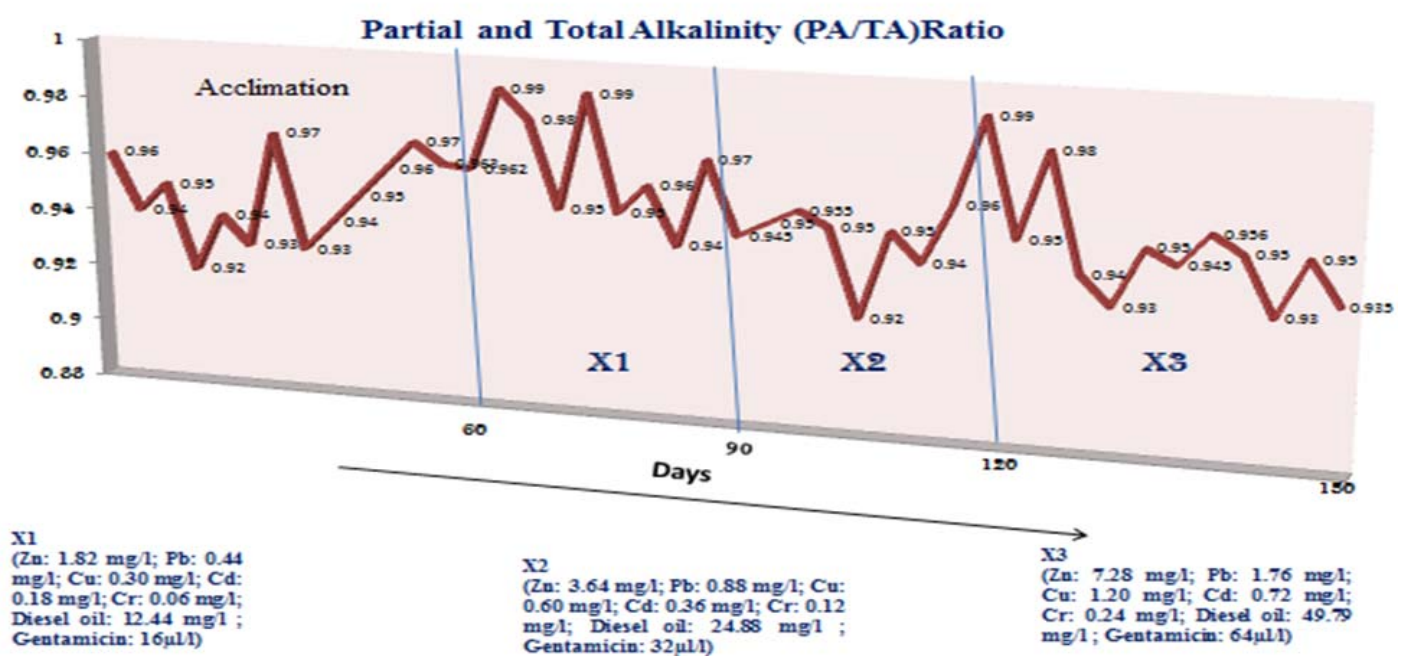

Fig. 4 The ratio of partial and total alkalinity values in UASB Reactor effluent throughout the entire experiment 


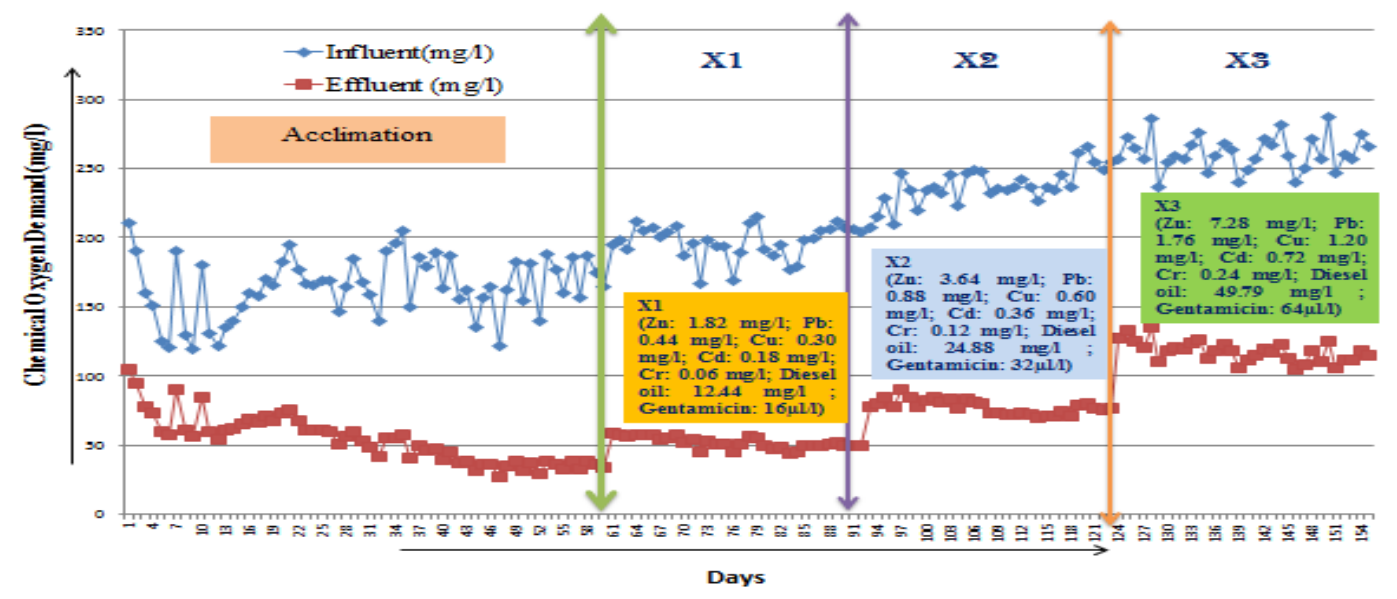

Fig. 5 Chemical Oxygen Demand values of UASB Reactor influent and effluent throughout the entire experiment

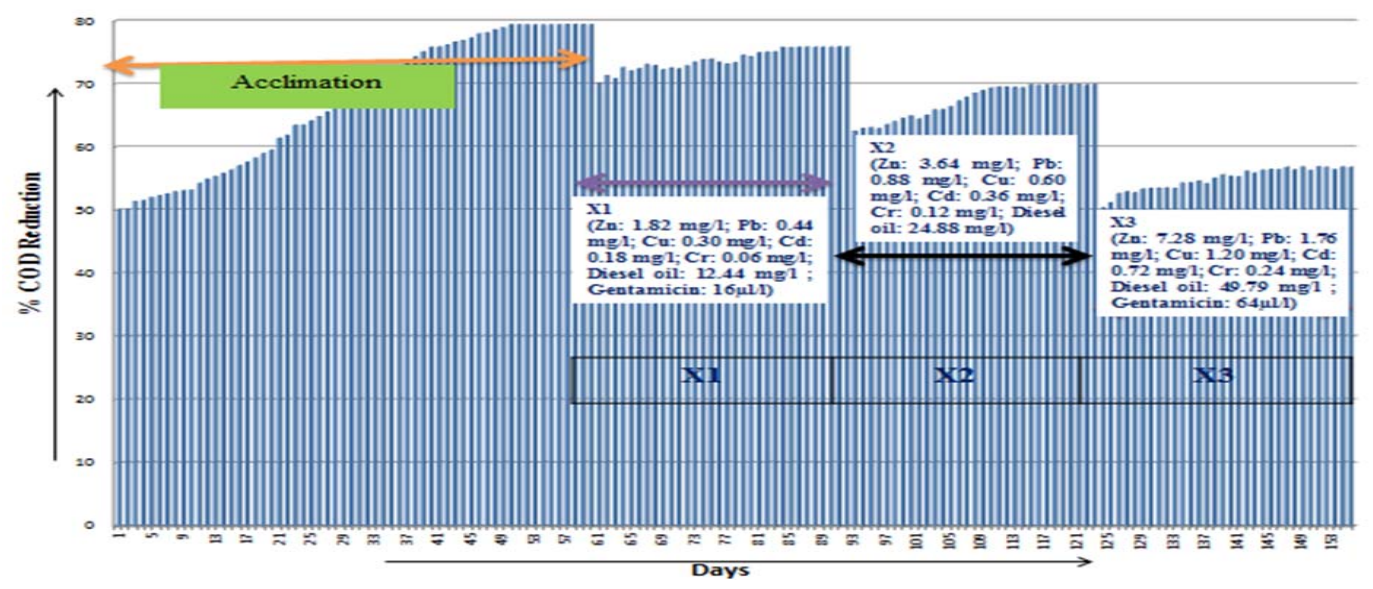

Fig. 6 Percentage COD Reduction values of UASB Reactor throughout the entire experiment

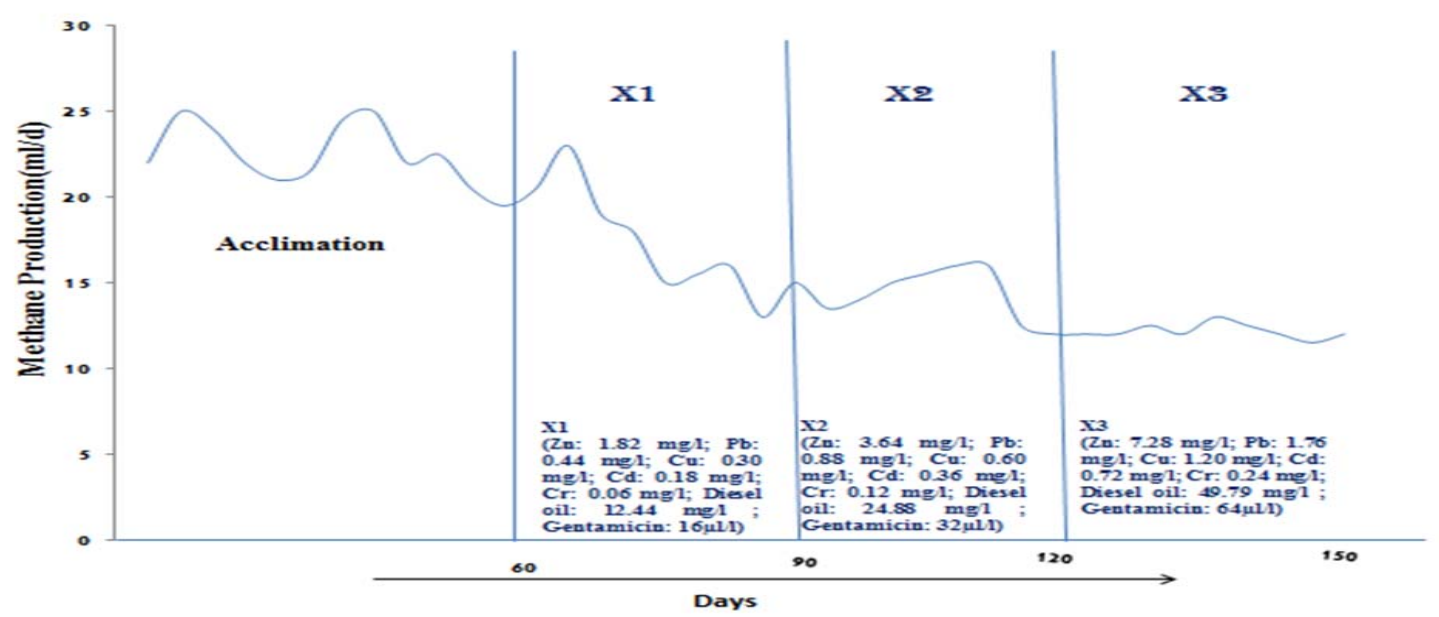

Fig. 7 Methane Production values of UASB Reactor throughout the entire experiment 


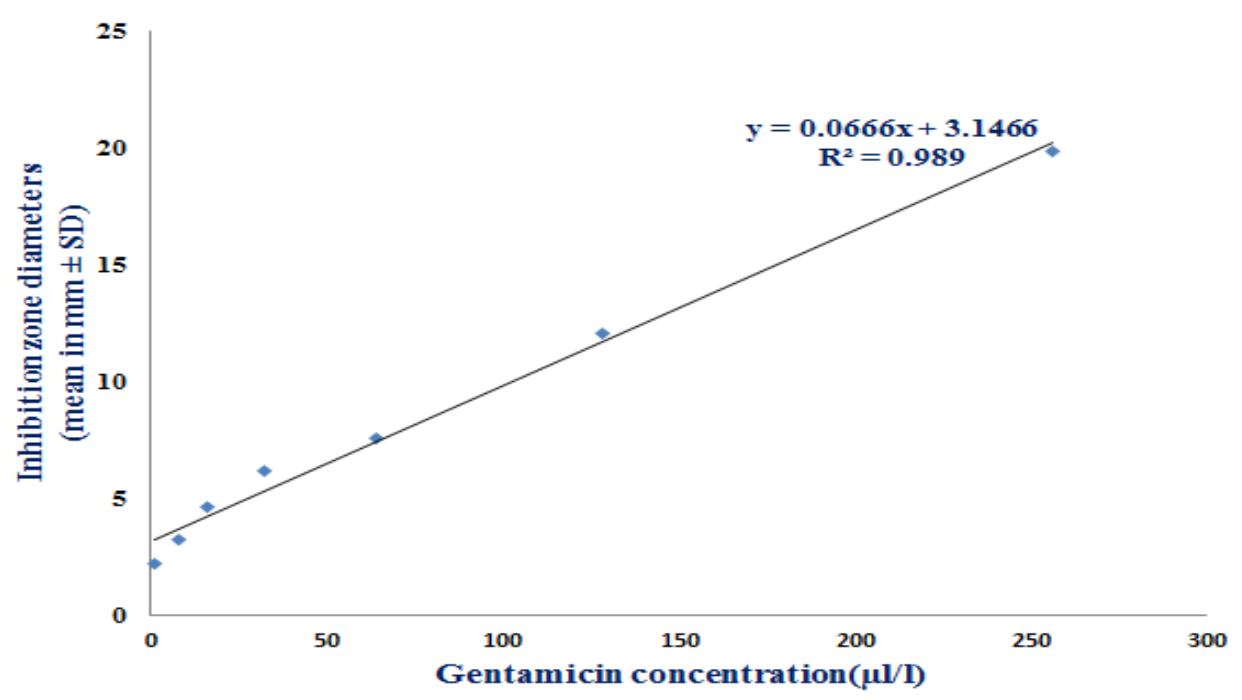

Fig. 8 Inhibition Zone Diameter for different concentration of gentamicin

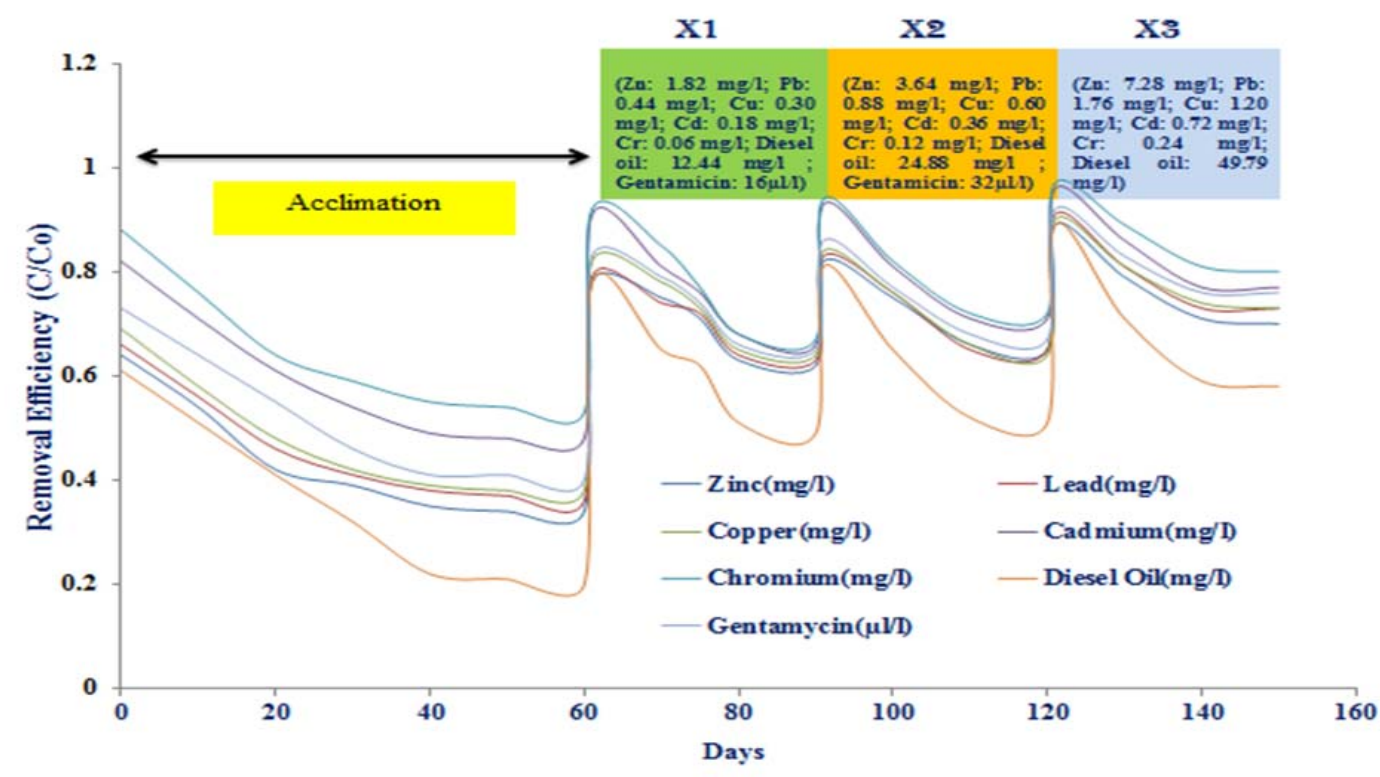

Fig. 9 Removal Efficiency of UASB Reactor for the all toxic augments throughout the entire experiment $(\mathrm{C}=$ final Concetration, $\mathrm{C} 0=$ initial Concentration) 

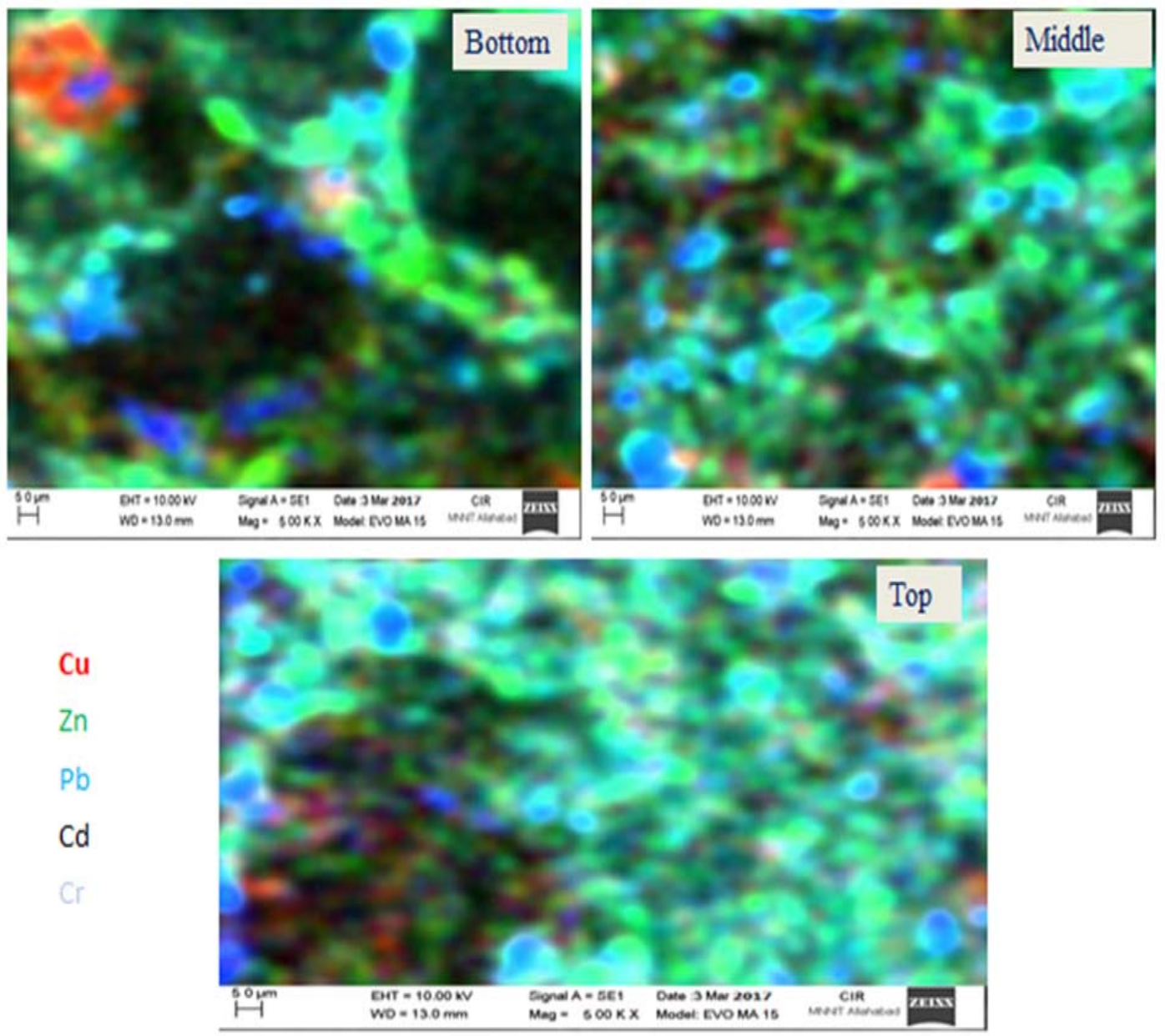

Fig. 10 Scaning Electron Microscopy(SEM) images of sludge collected from three different levels(bottom, middle and top)

Alkalinity values obtained throughout the entire experiment show that addition of $\mathrm{X} 1, \mathrm{X} 2$ and $\mathrm{X} 3$ doses in influent caused a slight instability in UASB reactor; however, the system buffer capacity was sufficient to overcome such instability. Total alkalinity and Volatile Fatty Acid (VFA) values in UASB Reactor effluent have been illustrated in fig. 3. The ratio of VFA and total alkalinity was found $0.25 \pm 0.04$ throughout the entire experiment. VFA and total alkalinity ratios, if higher than 0.30 are depicted disturbances in anaerobic biodegradation processes [32]. Thus results (fig. 3) have shown that reactor was stable during entire experiment. The ratio of partial and total alkalinity values in UASB Reactor effluent has been shown in fig. 4. The ratio of partial and total alkalinity values deals with a parameter that allows the assessment of volatile fatty acid accumulation in UASB reactor and it should be maintained less than 1 for prevention of acidification [33]. Throughout the entire experiment, the mean value of PA/TA ratio was found $0.95 \pm 0.02$, directing that if VFA accumulation occurred, it was maintained by the buffer capacity in the UASB reactor. Chemical Oxygen Demand values in UASB Reactor influent and effluent has been shown in fig. 5. During the acclimation phage COD concentration of UASB effluent remained below $50 \mathrm{mg} \mathrm{l}-1$, but when addition of X1, X2 and X3 doses started, this parameter increased until $80 \mathrm{mg} \mathrm{l}-1$ for $\mathrm{X} 1$ and $\mathrm{X} 2$ concentrations. When the dose X3 dose was added, the range of COD concentration in UASB effluent was around 110 and $135 \mathrm{mg}$ l-1. Percentage COD Reduction values of UASB Reactor have been shown in fig. 6. Regarding COD percentage removal, it had an average value up to $80 \pm 2.6 \%$ throughout entire the acclimation phase. The percentage removal was $72 \pm 2.4 \%$ when the dose of X1 was added; after that COD removal decreased approximately $15 \%$ when the higher doses were applied. The toxicity of metals, diesel oil and antibiotic to microorganisms is well studied; these substances can interact with intracellular iron-sulfur clusters of various proteins and inhibit their function under anoxic conditions [33]. Methane Production values of UASB Reactor throughout the entire experiment have been illustrated in fig. 7. Methane production ranged from 22 to $25 \mathrm{ml} \mathrm{d}-1$ during acclimation period and it sharply decreased when the dose of X1 was added until reached approximately $15 \mathrm{ml} \mathrm{d}-1$. After the addition of $\mathrm{X} 1$ and $\mathrm{X} 2$ in UASB influent, methane production stabilized, although the lowest methane production $(11 \mathrm{ml} \mathrm{d}$ 1) was found at higher doses. 
Calibration curve between antibiotic concentration (gentamicin) and inhibition zone can be seen in fig. 8 . Removal Efficiencies of UASB Reactor for the all toxic augments throughout the entire experiment have been shown in fig. 9. Scanning Electron Microscopy (SEM) images of sludge collected from three different levels (bottom, middle and top) have been displayed in fig. 10, showing the presence of copper, chromium, zinc, cadmium as well as lead in the samples. SEM results revealed that in sample1 (bottom), copper was the most abundant metal followed by others. Zinc concentration was found the highest in sample 3(top), followed by others. As found in results, low doses of toxic augments keep negative impact on the performance of UASB reactor.

The results achieved in this experiment illustrate that the presence of toxic augment, even at low concentrations, must be taken care off if anaerobic reactors are used to treat municipal wastewater containing three different concentrations of five heavy metals, diesel oil and antibiotic (gentamicin) will not cause total inhibition of granules in anaerobic reactor.

\section{IV.CONCLUSION}

In this experiment, a lab-scale UASB reactor was operated under a hydraulic retention time (HRT) of 7.5 hours and fed municipal wastewater added with three different concentrations of five heavy metals, diesel oil and antibiotic(gentamicin) having equal ratio as well as found in municipal wastewater (Zn: 1.82, 3.64 \& 7.28 mg/l; Pb: 0.44, 0.88 \& 1.76 mg/l; Cu: 0.30, 0.60 \& 1.20 mg/l; Cd: 0.18, 0.36 \& 0.72; Cr: 0.06, 0.12 \& 0.24 mg/l;

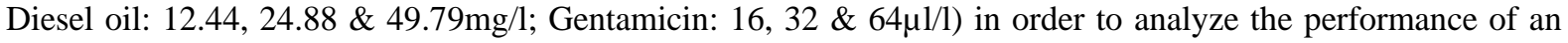
UASB reactor treating municipal wastewater with low metals, diesel oil and antibiotic concentrations. The following conclusions were drawn: heavy metal concentrations studied in this experiment affected adversely UASB reactor performance: addition of X1(Zn: $1.82 \mathrm{mg} / \mathrm{l} ; \mathrm{Pb}: 0.44 \mathrm{mg} / \mathrm{l}$; Cu: $0.30 \mathrm{mg} / \mathrm{l}$; Cd: $0.18 \mathrm{mg} / \mathrm{l}$; Cr: 0.06

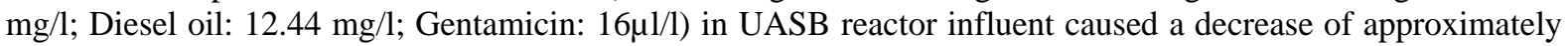
$30 \%$ in methane production; while the concentration of X2(Zn: $3.64 \mathrm{mg} / \mathrm{l} ; \mathrm{Pb}: 0.88 \mathrm{mg} / \mathrm{l}$; Cu: $0.60 \mathrm{mg} / \mathrm{l}$; Cd:

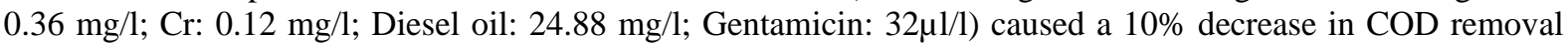
regarding the values found in the acclimation period. When the dose of X3(Zn: $7.28 \mathrm{mg} / \mathrm{l} ; \mathrm{Pb}: 1.76 \mathrm{mg} / \mathrm{l}$; $\mathrm{Cu}$ : $1.20 \mathrm{mg} / \mathrm{l}$; Cd: $0.72 \mathrm{mg} / \mathrm{l}$; Cr: $0.24 \mathrm{mg} / \mathrm{l}$; Diesel oil: $49.79 \mathrm{mg} / \mathrm{l}$; Gentamicin: 64 $\mu \mathrm{l} / \mathrm{l}$ ) was added, COD removal and methane production reached their lowest values ( $55 \%$ and $11 \mathrm{ml} / \mathrm{d}$, respectively).

Similar trends were found in alkalinity results: addition of X1 concentration (Zn: $1.82 \mathrm{mg} / \mathrm{l} ; \mathrm{Pb}: 0.44 \mathrm{mg} / \mathrm{l}$; Cu: $0.30 \mathrm{mg} / \mathrm{l}$; Cd: $0.18 \mathrm{mg} / \mathrm{l}$; Cr: $0.06 \mathrm{mg} / \mathrm{l}$; Diesel oil: $12.44 \mathrm{mg} / \mathrm{l}$; Gentamicin: $16 \mu \mathrm{l} / \mathrm{l})$ decreased 20\% alkalinity values in UASB effluent, whereas X3 concentration (Zn: $7.28 \mathrm{mg} / \mathrm{l} ; \mathrm{Pb}: 1.76 \mathrm{mg} / \mathrm{l}$; Cu: $1.20 \mathrm{mg} / \mathrm{l}$; Cd:

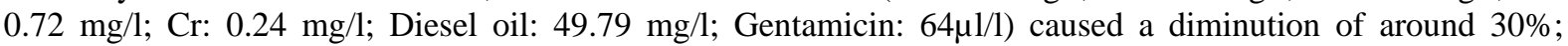
however, the system buffer capacity was able to overcome such instability, as partial and total alkalinity ratio results evidenced, and $\mathrm{pH}$ inside anaerobic reactor was not affected. Concerning metals geochemical distribution in the inoculum and the UASB reactor sludge, metal speciation results evidenced that the fraction which had the major affinity with heavy metals was the organically/sulfide bound fraction (F5), counting for approximately $96 \%$; however, further studies are needed in order to establish which is the weight of organic matter and sulfide in these metals binding.

Results from metal speciation performed demonstrated that these heavy metals were mainly associated with the organic fraction and sulfides in anaerobic sludge, thus its detrimental effect on UASB reactor performance derives from this fact. Still, it is important to note that even though system efficiency dropped due to the $\mathrm{X} 1 / \mathrm{X} 2 / \mathrm{X} 3$ concentrations presence in UASB influent, anaerobic digestion was not completely inhibited.

\section{REFERENCES}

[1] P. Torres, "Perspectives of anaerobic treatment of domestic wastewater in developing countries," Rev EIA, vol. 18(1), pp. 115-129, 2012.

[2] J. L. Chen, R. Ortiz, T. W. J. Steele and D. C. Stuckey, “Toxicants inhibiting anaerobic digestion: A review,” Biotechnol advances. DOI: 10.1016/j.biotechadv.2014.10.005, vol. 13(1), pp. 123-132, 2012.

[3] L. Otero-González, J. A. Field and R. Sierra-Álvarez, "Inhibition of anaerobic wastewater treatment after long-term exposure to low levels of CuO nanoparticles,” Water Res., vol. 58(1), pp. 160-168, 2014.

[4] C. Y. Lin and C. C. Chen, "Effects of heavy metals on the methanogenic UASB granule," Water Res., vol. 33 (2), pp. 409-416, 1999.

[5] M. S. Gould, E. J. Genetelli, "Effects of competition on heavy metal binding by aerobically digested sludges," Water Res. vol. 18 (3), pp. 123-126, 1984.

[6] K. K. Singh and R. C. Vaishya, "Bioremediation of Heavy Metal Using Consortia Developed from Municipal Wastewater Isolates," SJPSET vol. 9, pp. 57-66, 2017.

[7] K. K. Singh and R. C. Vaishya, "A study on kinetics of bio-surfactant produced by bacterial strains isolated from municipal wastewater” International Journal of Civil Engineering \& Technology, vol. 8(4), pp. 14-21, 2017.

[8] V. Ochoa-Herrera, G. León, Q. Banihani, J. A. Field and R. Sierra-Alvarez, "Toxicity of copper (II) ions to microorganisms in biological wastewater treatment systems,” Sci Total Environ., vol. 413(2), pp. 380-85, 2011.

[9] C. W. Jin, S. J. Zheng, Y. F. He, G. Zhou and Z. X. Zhou, "Lead contamination in tea garden soils and factors affecting its bioavailability,” Chemosphere, vol. 59(8), pp. 1151-1159, 2005.

[10] A. Fuentes, M. Lloréns, J. Sáez, A. Soler, M. A. Aguilar, J. F. Ortuño and V. F. Meseguer, "Comparative study of six different sludges by sequential speciation of heavy metals,” Biores Technol., vol. 99(3), pp. 517-525, 2008.

[11] A. Tessier, P. G. C. Campbell and M. Bisson, "Sequencial extraction procedure for the speciation pf particulate metals," Anal Chem., vol. 51(7), pp. 844-851, 1979. 
[12] M. Ortner, L. Rachbauer, W. Somitsch, W. Fuchs, "Can bioavailability of trace nutrients be measured in anaerobic digestion?,” Applied Energy, vol. 126(1), pp. 190-198, 2014.

[13] I. R. Leighton and C. F. Forster, "The effect of heavy metals on a thermophilic 26 Methanogenic blanket,” Biores Technol. vol., 63(2), pp. 131-137, 1999.

[14] M. B. Osuna, J. Iza, M. Zandvoort and P. N. L. Lens, “Essential metal depletion in an anaerobic reactor,” Water Sci Technol., vol. 48(1), pp. 1-8, 2003.

[15] K. K. Singh and R. C. Vaishya, "Isolation of Bacterial Isolates from Municipal Wastewater for Bioremediation of Anionic Surfactants,” International Journal of Scientific Progress \& Research, vol. 23, pp. 181-185, 2016.

[16] K. K. Singh, K. Gautam and R. C. Vaishya, "Plastic-Degrading Bacteria from Municipal Wastewater," International Journal of Scientific Progress \& Research, vol. 21, pp. 147-154, 2016.

[17] I. D. Barceló-Quintal, H. E. Solís-Correa, P. Ávila-Pérez, E. López-Galván, J. García-Albortante and S. Gómez-Salazar, "Determination of $\mathrm{Cd}, \mathrm{Cu}$, and $\mathrm{Pb}$ in sediment from a Mexican reservoir receiving wastewaters," Biol Trace Element Res., vol. 148(1), pp. 122-132, 2012.

[18] APHA, AWWA and WEF, "Standard methods for the examination of waste and wastewater," 20th ed, Washington DC: American Public Health Association, 1998.

[19] M. Soto, R. Méndez and J. Lema, "Methanogenic and non-methanogenic activity tests theoretical basis and experimental set-up," Water Res., vol. 27(8), pp. 1361-1376, 1993.

[20] E. D. Van Hullebusch, S. Utomo, M. H. Zandvoort and P. N. L. Lens, "Comparison of three sequential extraction describe metal fractionation in anaerobic granular sludges,” Talanta. Vol., 65(2), pp. 549-558, 2005.

[21] M. H. Zandvoort, E. D. Van Hullebusch, J. Gieteling and P. N. L. Lens, "Granular sludge in full-scale anaerobic bioreactors: Trace element content and deficiencies. Enzy Microbial Tech., vol. 39(2), pp. 337-346, 2005.

[22] S. F. Aquino and D. C. Stuckey, "Bioavailability and toxicity of metal nutrients during anaerobic digestion,” J Environ Eng., vol. 133(1), pp. 28-35, 2007.

[23] W. Calmano and U. Forster, "Chemical extraction of heavy metals in polluted river sediment in Central Europe," Sci. Total Environ., vol. 28(3), pp. 77-90, 1983.

[24] A. Fuentes, M. Lloréns, J. Sáez, A. Soler, M. A. Aguilar, J. F. Ortuño and V. F. Meseguer, "Simple and sequential extractions of heavy metals from different sewage sludges,” Chemosphere, vol. 54(8), pp. 1039-1047, 2004.

[25] A. Filgueiras, I. Lavilla and C. Bendicho, "Chemical sequential extraction of metal partitioning in environmental solid simples,” J Environ Monitor., vol. 4(3), pp. 823-857, 2002.

[26] N. Zhu, Q. Li, X. Guo, H. Zhang and Y. Deng, "Sequential extraction of anaerobic digestate sludge for the determination of partitioning of heavy metals,” Ecotox Environ Safety, vol. 102(1), pp. 18-24, 2014.

[27] K. K. Singh, K. Gautam and R. C. Vaishya, "Bioremediation of Petroleum Hydrocarbons from Crude Oil contaminated site by Gravimetric Analysis,” International Journal of Scientific Progress \& Research, vol. 22, pp. 75-78, 2016.

[28] K. K. Singh and R. C. Vaishya, "Biodegradation of Recalcitrant Pollutants by Bacterial Isolates from Municipal Waste Water," International Journal for Technological Research in Engineering, vol. 3, pp. 2256-2266, 2016.

[29] V. Ochoa-Herrera, G. León, Q. Banihani, J. A. Field and R. Sierra-Alvarez, "Toxicity of copper(II) ions to microorganisms in biological wastewater treatment systems,” Sci Total Environ., vol. 380(5), pp. 412-413, 2011.

[30] T. D. Hayes and T. L. Theis, "The distribution of heavy metals in anaerobic digestion,” J Water Pollution Control Fed., vol. 50(1), pp. 61-72, 1978

[31] C. White and G. M. Gadd, “Copper accumulation by sulfate reducing bacterial biofilms,” FEMS Microbiol Lett., vol. 183(2), pp. 313318, 2000.

[32] A. Jahn and P. H. Nielson, “Cell biomass and exopolymer composition in sewer biofilms,” Water Sci Technol., vol. 37(1), pp. 17-24, 1998.

[33] Flemming HC, Wingender J, "Relevance of microbial extracellular polymeric substances (EPSs), Part I. Structural and ecological aspects. Water Sci Technol. vol. 43(6), pp. 1-8, 2001.

\section{AUTHOR PROFILE}

Kanhaiya Kumar Singh, Senior Research Fellow, Department of Civil Engineering, Motilal Nehru National Institute of Technology-Allahabad, 211004, India, E-mail: rce1454@mnnit.ac.in

Rakesh Chandra Vaishya, Professor, Department of Civil Engineering, Motilal Nehru National Institute of Technology-Allahabad, 211004, India, E-mail: rcvaishya@mnnit.ac.in

Arnav Gupta, B. Tech Student, Department of Civil Engineering, Birla Institute of Technology \& Science, Pilani-333031, Rajasthan, India, E-mail: arnavcooldude7@gmail.com 